\title{
Freshwater ostracods as environmental tracers
}

\author{
F. Ruiz $\cdot$ M. Abad $\cdot$ A. M. Bodergat $\cdot$ P. Carbonel $\cdot$ J. Rodríguez-Lázaro $\cdot$ \\ M. L. González-Regalado • A. Toscano • E. X. García • J. Prenda
}

Received: 6 October 2011/Revised: 5 March 2012/Accepted: 13 November 2012/Published online: 29 March 2013

(C) The Author(s) 2013. This article is published with open access at Springerlink.com

\begin{abstract}
This paper revises the response of freshwater ostracods to different environmental conditions and anthropogenic impacts, with a worldwide overview of the potential use of these microcrustaceans as bioindicators and several examples of applications in different scenarios. The development of either a single species or an ostracod assemblage is influenced by physical-chemical properties of waters (salinity, temperature, $\mathrm{pH}$, dissolved oxygen), hydraulic conditions, bottom grain sizes or sedimentation
\end{abstract}

F. Ruiz ( $₫)$ · M. Abad · M. L. González-Regalado .

A. Toscano

Departamento de Geodinámica y Paleontología,

Facultad de Ciencias Experimentales, Universidad de Huelva, 21071 Huelva, Spain

e-mail: ruizmu@uhu.es

\section{A. M. Bodergat}

Départment Sciences de la terre, Centre de Paléontologie Stratigraphique et Paléoécologie, Université Claude Bernard,

15-43 Boulevard du 11 novembre 1918, Villeurbanne, France

P. Carbonel

Départment de Géologie et Océanographie, Université de Bordeaux I, Avenue des Facultés, 33405 Talence Cédex, France

J. Rodríguez-Lázaro

Departamento de Estratigrafía y Paleontología, Facultad de Ciencias, Universidad del País Vasco, Apartado 644, 48080 Bilbao, Spain

\section{E. X. García}

Departamento de Botánica y Zoología, Centro Universitario de Ciencias Biológicas y Agropecuarias, Universidad de Guadalajara, 45110 Jalisco, Mexico

\section{J. Prenda}

Departamento de Biología Ambiental y Salud Pública, Facultad de Ciencias Experimentales, Universidad de Huelva, 21071 Huelva, Spain rates. In addition to population and community changes, morphological and geochemical changes can also be detected in the ostracod carapace, which serves as a tracer of the water quality. All these features permit to delimit the spatial effects of urban sewages, mining effluents, agricultural wastes, watershed deforestation or road building. These data are the basis for the palaeoenvironmental reconstruction of cores, with an interesting application to archaeology. In addition, favourable results of recently developed bioassays, coupled with an important variability of local assemblages under changing conditions in both waters and sediments, suggest that these microcrustaceans may included between the most promising sentinels groups in freshwater areas. These microcrustaceans show high sensitivity to pesticides, herbicides, heavy metal pollution and oil inputs.

Keywords Anthropogenic impact - Biotechnology · Environmental parameters · Ostracods

\section{Introduction}

Numerous papers have analyzed the importance of freshwater ecosystems as an essential part of human cultures. Although they occupy only about $1 \%$ of the Earth's surface, both lotic and lentic environments are central to the society. Nevertheless, they are being subjected to unprecedented levels of human disturbance with variable incidence on waters, sediments and biota (Saunders et al. 2002).

Different groups of organisms have been proposed as bioindicators and/or biomonitors (see Rinderhagen et al. 2000 for distinction) to test these changes. Among the macrofaunal organisms, fishes ( $\mathrm{Lu}$ et al. 2009), mussels 
(Angelo et al. 2007), gastropods (Piyatiratitivorakul and Boonchamoi 2008) or plants (Akguc et al. 2010) are usually used for this purpose. In addition, several meiofaunal groups are also included as sentinels of human-induced changes in these freshwater environments, such as diatoms (Rimet and Bouchez 2011) or nematodes (Zhu et al. 2001).

In this last category, different studies have demonstrated the importance of some microcrustaceans (e.g. ostracods) as keystone species on production and community metabolism of micro- or mesocosm freshwater beds, playing an interesting role in determining the structure of these systems (Lawrence et al. 2002). In these microenvironments, ostracods compete with oligochaetes and amphipods for food sources (Modig et al. 2000) and all these groups are predated by fishes or gastropods.

This review attempts to analyse the potential of ostracods as environmental tracers in recent freshwater ecosystems. As ostracods occur in every aquatic environment, they can be applied as bioindicators when other groups cannot be used (e.g., groundwaters, stagnant and temporary waters). Results can be applied to both evaluations of biotic changes produced by anthropogenic activities or palaeoecological/ archaeological interpretations using sediment cores.

\section{Freshwater ostracods and environmental parameters}

Correlation between different environmental variables and ostracod species has been demonstrated in numerous field investigations. A brief review is given below.

Water and ostracods

\section{Salinity}

Salinity is considered a major factor regulating aquatic community structure in freshwater environments, especially in hydrologically closed lakes and wetlands, although there are no simple relationships between ostracod faunas and this variable. Some euryhaline species are found in limnic waters but they can inhabit even hypersaline environments, whereas others (Ilyocypris bradyii, Candona candida, Fabaeformiscandona levanderi, $F$. protzi, Herpetocypris reptans) are limited to salinities down to $6 \%$ (see Fig. 1).

\section{Temperature}

Seasonal or depth-water differences of temperature may explain important changes on both ostracod density and diversity. Low temperatures seem to favour the development of some species, e.g., Candona neglecta or Darwinula stevensoni (Martens and Tudorancea 1991;
Külköylüoglu and Yilmaz 2006), while other species (Isocypris beauchampi, Cyprideis torosa, Cyclocypris ovum) increase their abundances with higher temperatures (Rieradevall and Roca 1995). A third group (e.g., Cytherissa lacustris, Heterocypris incongruens) presents a relatively broad tolerance to temperature changes (Danielopol et al. 1990; Külköylüoglu 2004).

\section{Oxygen-dissolved concentrations}

Some species (e.g., Darwinula stevensoni) are very sensitive to oxygen depletion, whereas others that live in shallow muddy ponds may tolerate low oxygen concentrations for short time periods (e.g. Candona candida, Paracyprideis fennica, Cypria opthalmica or Heterocypris incongruens) and a third group (e.g., Heterocypris sorbyana, Candona neglecta) is tolerant to hypoxic conditions (e.g., Dole-Olivier et al. 2000; Meisch 2000; Altinsacli and Griffiths 2001).

Temporal anoxic conditions cause usually marked falls in ostracod assemblage diversity levels (Rieradevall and Roca 1995). The time delay in responding to these low oxygen levels has been estimated at less than 1 month (Martin-Rubio et al. 2005).

$p H$

Most freshwater ostracods prefer alkaline or slightly acidic waters, although some species can tolerate a wide range of $\mathrm{pH}$ from 4.6 to 13 (Fig. 1) and others were found even in highly acidic waters (e.g. Fryer 1993). In general, ostracod species are absent at a $\mathrm{pH}<5$, because calcium uptake for carapace calcification is difficult in acid waters (Griffiths and Holmes 2000; Boomer et al. 2006).

\section{Nutrient levels}

Some ostracod species are very sensitive to high concentrations of several pollutants. Phosphates cause high disturbances in some species of Herpetocypris, whereas the amount of nitrates affect remarkably to Candona neglecta (Milhau et al. 1997). Some species (e.g. Ilyocypris inermis) are absent in disturbed sites with high nutrient levels (Pieri et al. 2012).

Depth water

Although it is very difficult to obtain a statistical correlation between depth and either ostracod diversity or the abundance of individual species, some general patterns have been established in stable freshwater environments (e.g., Fig. 2). Some species (Limnocythere inopinata, Darwinula stevensoni, Ilyocypris echinata) are typical of 


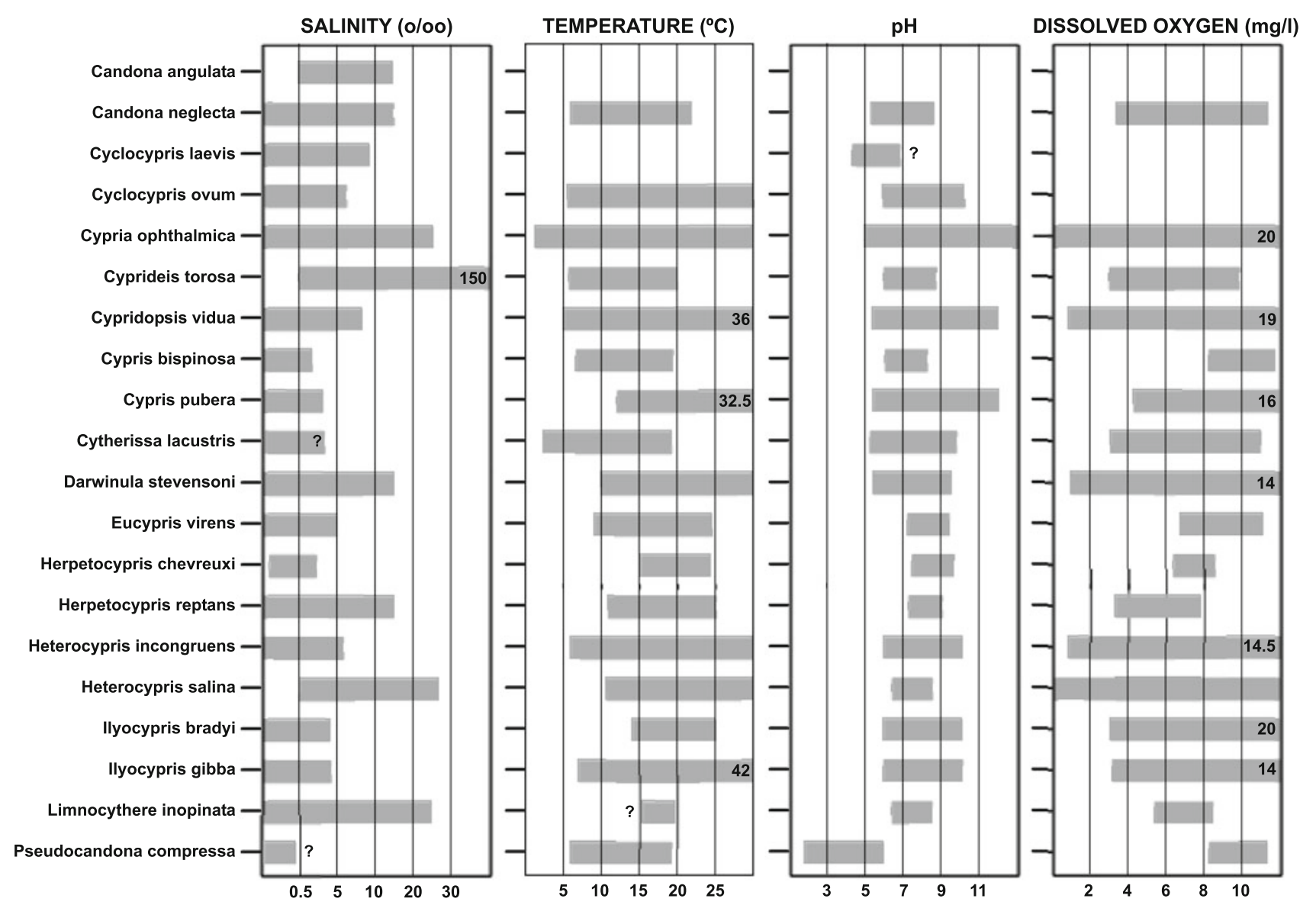

Fig. 1 Life physico-chemical conditions of twenty selected freshwater species (>100 papers revised from 1969 to 2011)

the benthos of shallow areas, whereas Candona angulata, C. candida, Cryptocandona reducta, Cypria ophthalmica, Cyclocypris ovum, Cytherissa lacustris, Potamocypris smaragdina or Limnocythere sancti-patricii can be also present in the deeper benthos ( $>40 \mathrm{~m}$ deep) (Griffiths et al. 2002; Li et al. 2010).

Depth water is clearly linked to climatic changes in some areas. In temporal lakes, swimming species are dominant during wet, deep-water periods, whereas burrowing species characterize the dry, shallow-water periods and scarce individuals are found if lakes dry out completely (Curry 2003).

\section{Hydraulic conditions}

Ostracods avoid generally high water velocities by moving inside sediments or vegetation, although they may be abundant in interstitial habitats of rapidly flowing streams (Creuzé des Chatelliers and Marmonier 1993). Moreover, some species present significant positive correlation with water turbidity (Yilmaz and Külköylüoglu 2006).

In addition, the thanatocoenosis distribution may be indicative of the seasonal hydrodynamic conditions.
Isolated valves of freshwater species (e.g. Cytherissa lacustris, Lineocypris sp.) are transported even $2 \mathrm{~km}$ seaward during high flows, whereas only marine species were found during low flows in the same area (Ruiz et al. 1998).

\section{Species traits and habitat utilization}

Long life spans, late maturity, low fecundity and low migratory ability, medium size and geometric carapace shape are species traits of ostracods living in interstitial and hypogean habitats. In permanent flowing and standing surface waters, the abundant epigean species have long life spans, various body forms, large size and some of them give parental care. On the contrary, in temporary ponds and stagnant waters, most of the species have short life spans, high migratory ability, high tolerance desiccation and are spherical or cylindrical shape in temporary ponds and stagnant waters (Marmonier et al. 1994).

The outline of ostracods carapace can provide valuable information on the stability/instability of the environment. Species of Candoninae have triangular, trapezoidal or elongate valves with accurate posterior margin in stable 


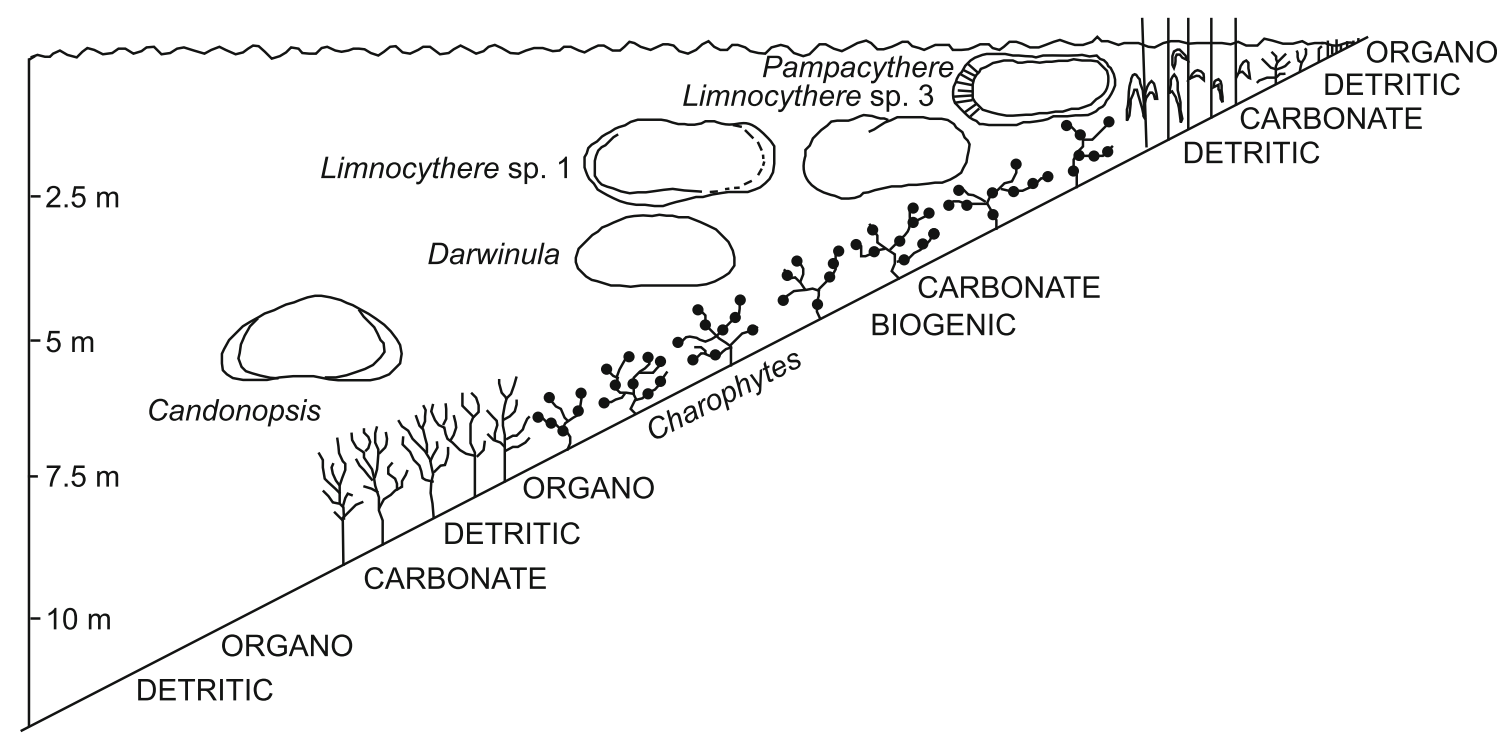

Fig. 2 Distribution of the main groups of species of ostracods related to water depth and sediment type in Lake Huinaymarca, Bolivia (modified from Mourguiart et al. 1986)

environments, whereas Cypria species with a sub-circular outline characterizes unstable environments (Pipik and Bodergat 2005).

Sediments and ostracods

\section{Grain size}

The influence of this factor is variable on the ostracod assemblages. In some lakes, the ostracod survival rates decreased with decreasing particle size (Donahue and Irvine 2003), whereas the effect of grain size distribution is likely to be insignificant on ostracod populations of some freshwater ponds and river biofacies (Ikeya and Hanai 1982). Some species (e.g., Limnocythere inopinata, $L$. sanctipatricii, Leucocythere mirabilis, Ilyocypris bradyii) usually occurs in fine-grained sediments (Lambert 1997), in contrast with the high abundances of these microcrustaceans found in coarse facies of some karstic lakes and alpine streams (e.g. Suren 1992). In addition, both this parameter and salinity changes may have a remarkable effect on the ornamentation pattern of selected species in other areas (Fig. 3: Cyprideis torosa).

\section{Sedimentation rates}

In some lakes subjected to a increasing deforestation around them, these crustaceans are very sensitive to high sedimentation ratios derived from the rapid erosion, with reduction in species richness up to $40 \%$ in the shallowest areas. In these lakes, ostracods are more affected than diatoms by sedimentation (Cohen et al. 1993). This decrease has been also observed on estuarine environments, coinciding with increased sedimentation rates as a result of land modifications (Hayward et al. 2004).

\section{The ostracod carapace as environmental tracer}

\section{Ornamentation}

Surface external ornamentation has been also applied in environmental studies. Cytherissa lacustris, Limnocythere inopinata or Cyprideis torosa show smooth, punctuated, reticulated or noded carapaces (Fig. 4) depending on salinity range (Vesper 1975; Zhai et al. 2010) and have rounded pores in freshwater environments, whereas irregular pores are present mainly in oligohaline to hypersaline waters. Rosenfeld and Vesper (1977) proposed a graphic diagram to calculate palaeosalinities based on percentages of round, elongate and irregular sieve pores of this species, which have been used in the palaeoenvironmental reconstruction of sediment cores (Gliozzi and Mazzini 1998). Nevertheless, Keyser (2005) thinks the noding problem in C. torosa is mainly an osmotic control one, because the noded specimens are found in low salinity waters but also in low calcium content. According to this author, ecophenotypism in ostracod species is probably the result of a multifactorial system.

Influence of temperature cannot be omitted. The most reticulated carapaces are also the richest in $\mathrm{Mg}$ (Fig. 3; Carbonel and Tölderer-Farmer 1988). 
Fig. 3 Influence of the granulometry (edaphic support) on the ornamentation of Cyprideis torosa. Specimens have been collected from the South of Spain (Alicante province), Southwest of France (Camargue, Bouches-du Rhône) and Northwest of France (Noirmoutier Island) (modified from Bodergat 1983)

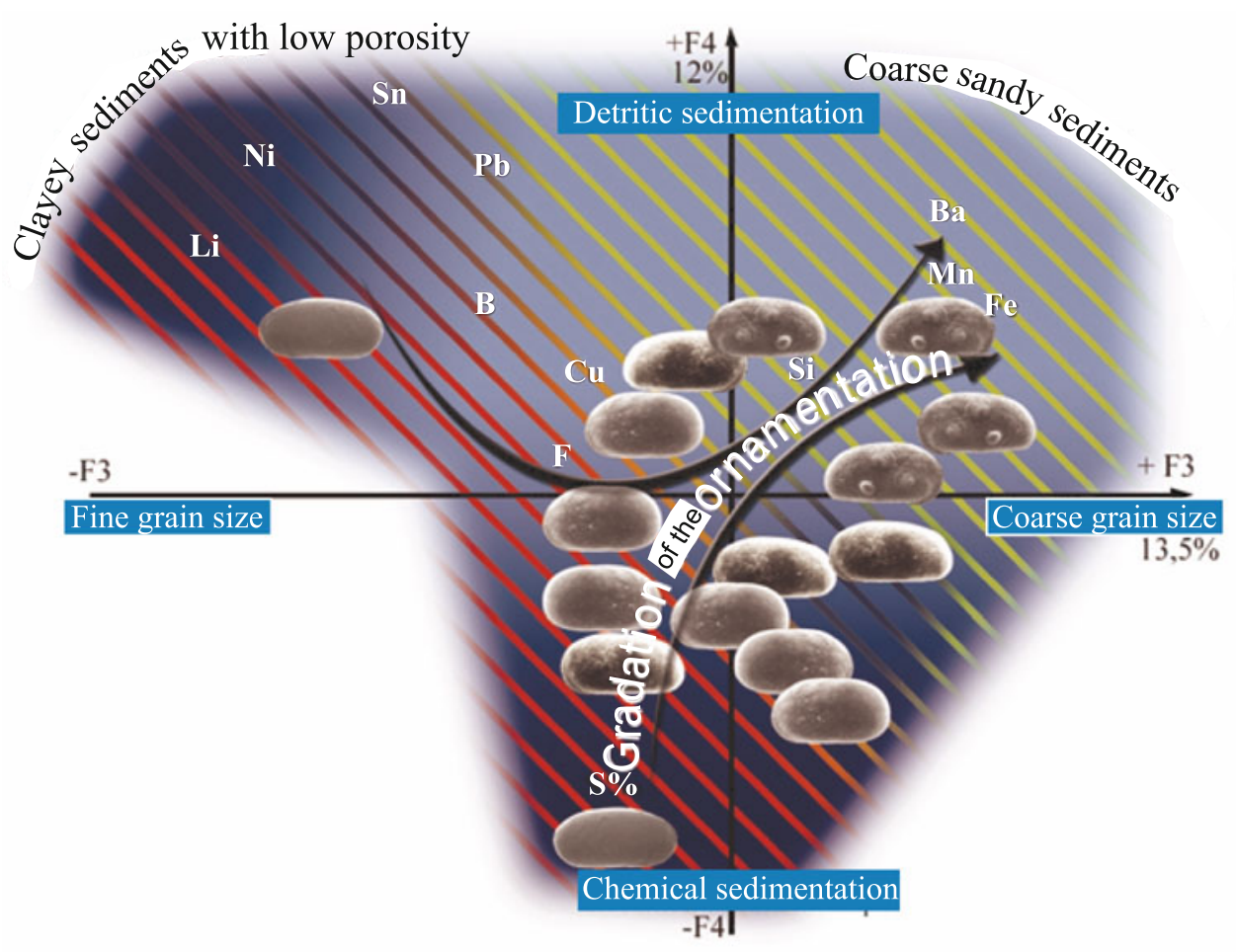

Coarse grain size

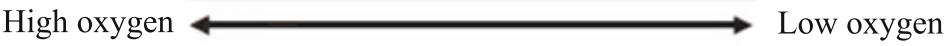

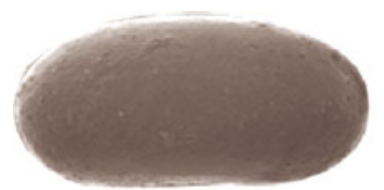

Smooth

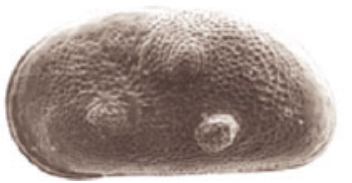

Noded

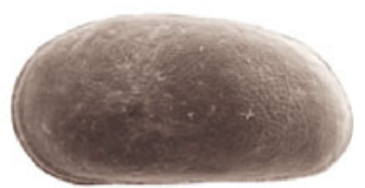

Reticulated

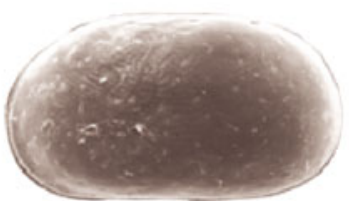

Punctuated
Fig. 4 Different types of ecophenotypic ornamentation on Cyprideis torosa (modified from Bodergat 1983)

\section{Geochemistry}

Trace elements and stable isotope geochemistry of fossil carapaces can provide very useful palaeoenvironmental informations (e.g. Jin et al. 2011). In a freshwater species, the phosphorus content (in \% or ppm) of the carapace may be similar in the same environment and can change between different geographical localities, being indicative of changing geochemical conditions (e.g. Bodergat 1979).

In addition, it is important to indicate the position of the analysis in the ostracod carapace, because the percentages of an element change between internal or external zones of the same carapace (Carbonel and Tölderer-Farmer 1988). According to Rio et al. (1997), antero-posterior differences are evident and variations between inner and outer parts of the shell are less frequent. If the elements associated with mineral inclusions have a rather homogeneous distribution, those involved in biological pathway $(\mathrm{P}, \mathrm{Na}, \mathrm{S}, \mathrm{Mg}, \mathrm{Ca})$ have a heterogeneous distribution.

\section{Environmental applications}

Industrial/mining wastes and urban effluents

Wastes derived from different pollution sources provoke important changes on both ostracod density and diversity. In heavily organic-polluted waters close to urban or industrial concentrations, ostracods are usually very scarce and can even disappear (Poquet et al. 2008). These effects diminish generally downstream in some rivers, with the 
presence of different ostracod assemblages along a gradient from high pollution towards the final "recovery" zone (Fig. 5; Mezquita et al. 1999a, b).

Mining activities produce similar effects on the ostracod assemblages, with a rapid decline of species found near the point of treated polluted underground waters (Van der Merwe 2003). Nevertheless, a part of this pollution may be eliminated by some ostracod species, such as Herpetocypris chevreuxi (Onderikova 1993).

\section{Agricultural wastes}

The widespread and massive use of fertilizers, pesticides and herbicides causes a decrease in ostracod richness (Rossi et al. 2003), although some species are resistant to pesticides or organic pollution (Lim and Wong 1986). Tolerant taxa are dominant in lowland springs with high nitric nitrogen contents $(>800 \mu \mathrm{M})$ derived from a diffuse pollution of agricultural origin (Rosetti et al. 2004), whereas important increase of phosphate contents has been related to the absence of living specimens in the upper sediments of some lakes (Wünnemann et al. 2006).

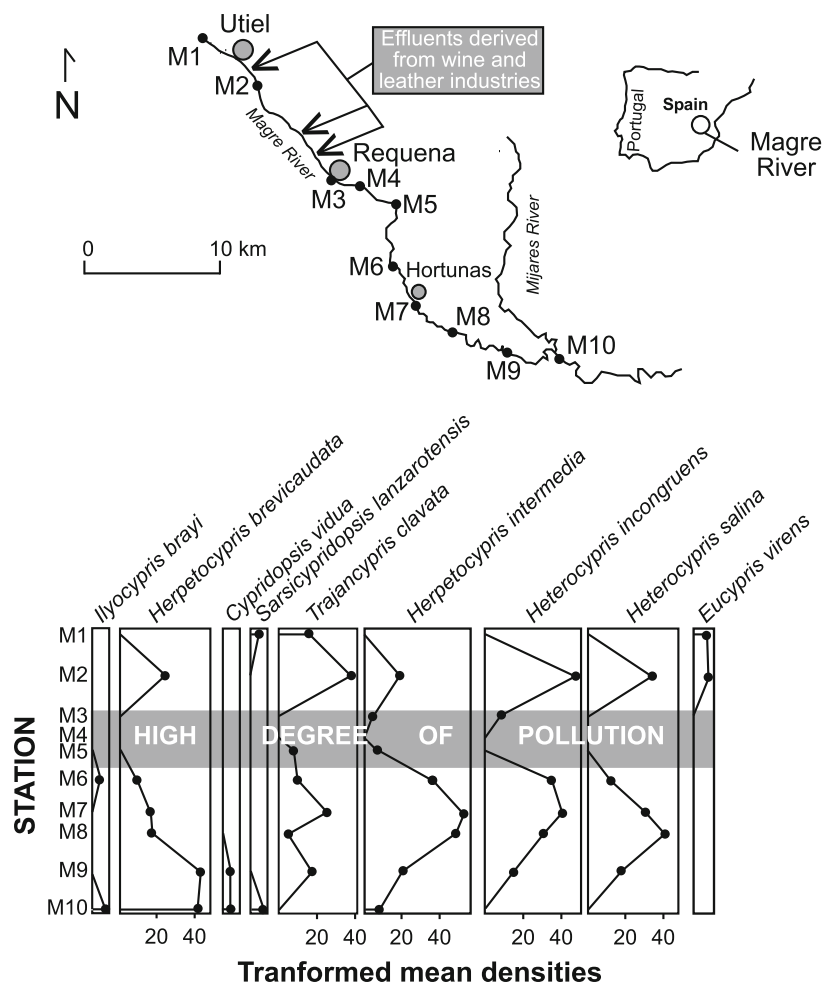

Fig. 5 Impact of industrial effluents on the ostracod populations of Magre River (Eastern Spain), with transformed average density values calculated for seven monthly field samplings (January 1995July 1995). The scales of abundance indicate $10 \ln (x+1)$, where $x$ is the mean number of individuals per $\mathrm{m}^{2}$ (modified from Mezquita et al. Mezquita et al. 1999a, b)
Influence of other human activities

Other anthropogenic activities have also an important influence on the ostracod species richness. Watershed deforestation and road building, together with municipal and industrial discharges, result in sediment inundation of lacustrine habitats and decreasing ostracod diversities (up to $30 \%$ ) at the high-disturbance sites (Alin et al. 1999).

The impact of catchment land uses is also detected. In several small streams, few individuals and taxa occupied the hyporheic zones of streams draining hill-country catchments under pasture, which leads to hill-slope slumping, channel narrowing, an increasing erosive forces in the stream channel and reduces the habitable hyporheic zone (Boulton et al. 1997).

\section{Palaeoenvironmental applications}

Palaeoenvironmental trends

Numerous studies have been focused on palaeoenvironmental reconstructions based on a multivariate analysis (stratigraphic units, mineralogical data, macro- and microfaunal assemblages, isotopic trends) of cores collected in freshwater environments, including the ostracod analysis (De Deccker and Forester 1988; Lord et al. 2011). Autoecological stratigraphic analysis of ostracod assemblages is especially interesting in lakes where the persistence of local populations is often threatened by disturbance and changes in both water availability and quality. In sub-recent studies carried out on sediment cores (e.g. Ramdani et al. 2001), changes in the ostracod assemblages or population age structure have been related to the introduction of new predators (Fig. 6a), construction of a freshwater drainage channel (Fig. 6b), or increase of the water management for agriculture (Fig. 6c).

On the other hand, alternances of both brackish/marine or freshwater associations allowed the recognition of salinity variations that could be related to Pleistocene sealevel changes (Gliozzi and Mazzini 1998), salinity and lake-level variations (Holmes et al. 2007) or palaeogeographical reconstructions (Ruiz et al. 2004). These assemblage changes, together with isotopic studies applied to ostracod carapaces, are very useful to reconstruct climatic changes (warm/cold phases), depth-water variations or hydrological/hydrochemical conditions (e.g. Anadón and Gabàs 2009).

Some morphological features (size, shape) of ostracod species have been used to reconstruct palaeoenvironmental conditions. Occurrence of large sized and geometric ostracod carapaces indicates a stable environment and the presence of different morphologies permits to attest rift 
Fig. 6 CASSARINA Project. Evolution of ostracod assemblages and palaeoenvironmental reconstructions of three cores collected in three North African wetland lakes (modified from Ramdani et al. 2001). Bars represent the number of individuals in $10 \mathrm{~cm}^{3}$ sediment

\section{CORE RHAB2. MERJA SIDI BOU RHABA (MOROCCO)}

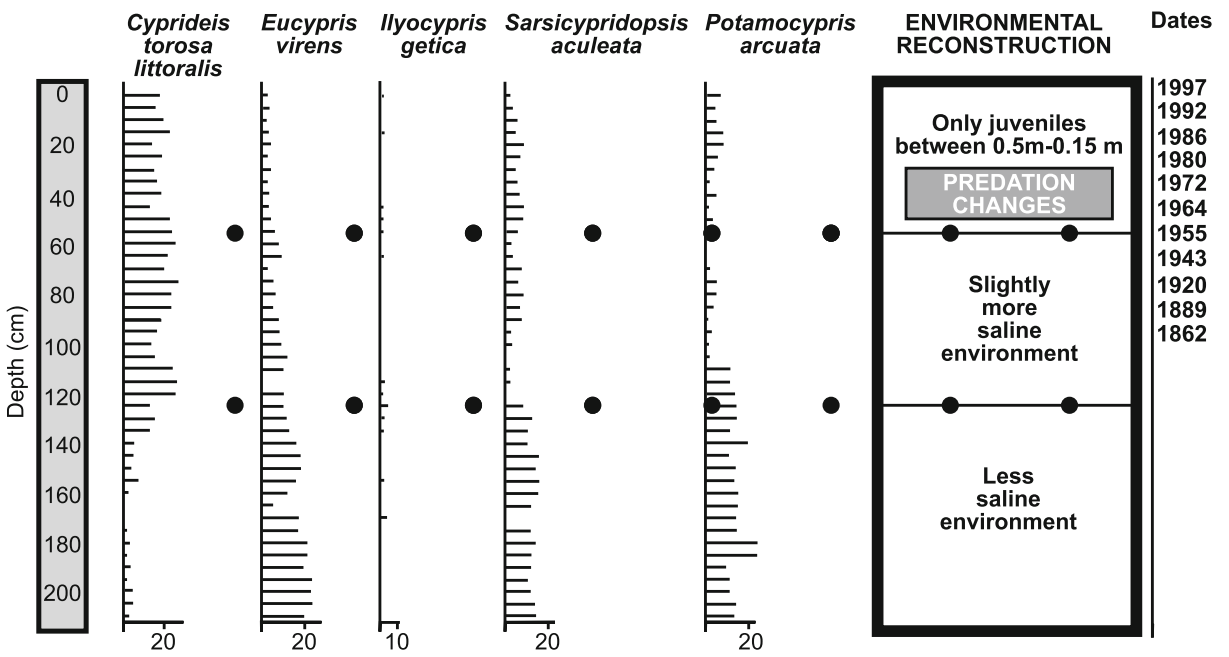

\section{CORE ZERGI. MERJA ZERGA (MOROCCO)}

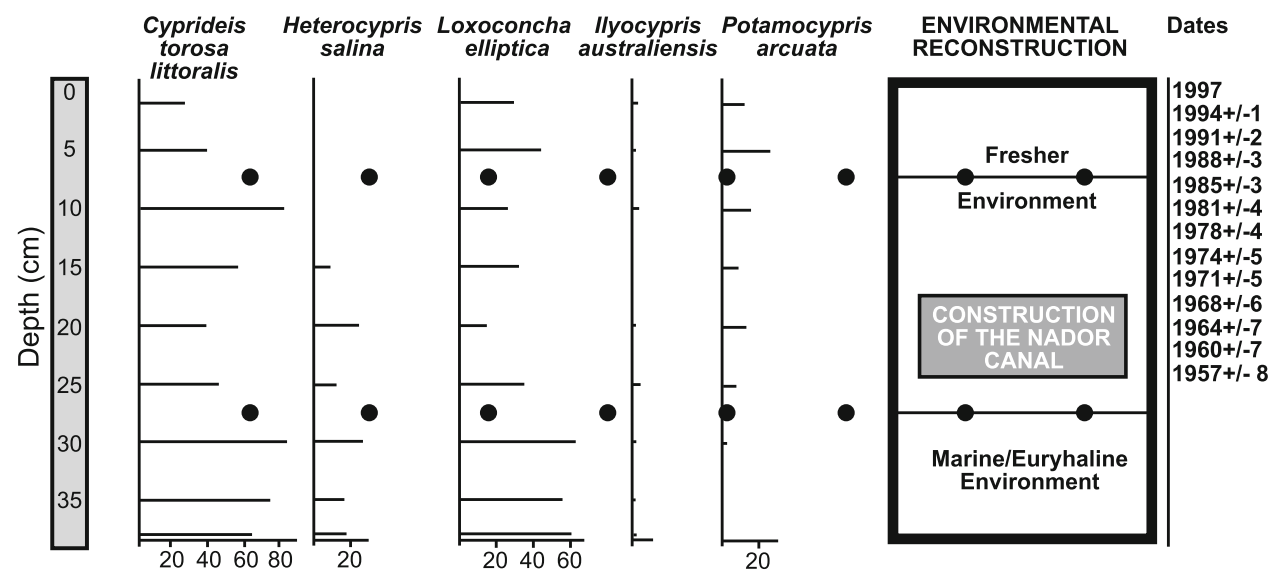

\section{CORE MANZI. MERZALA LAKE (EGYPT)}

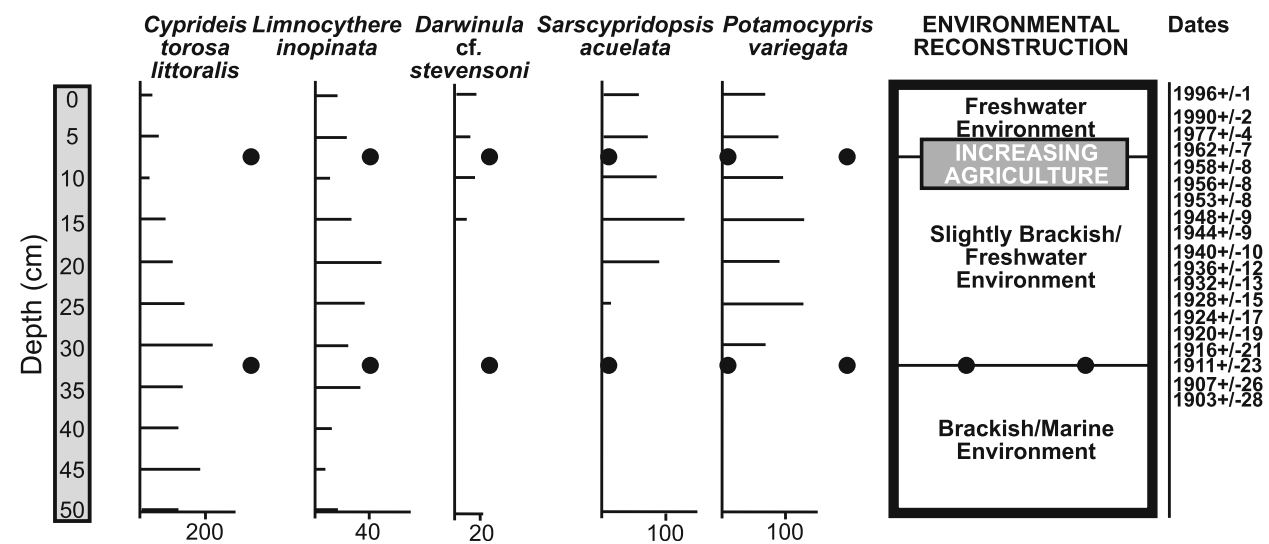

activities, without any variations of the sedimentology (Hugueney et al. 1999).

Nevertheless, Holmes (1996) indicated a number of problems related to: (1) methods used for extraction of ostracod shells from sediment and their subsequent cleaning; (2) post-mortem diagenesis and alteration of the shell; (3) complications with the calcification mechanism; (4) spatial and temporal variability in shell composition; 
(5) the ecological tolerances of individual species; and (6) the relationships between shell chemistry and palaeohydrology.

Palaeoclimatic reconstructions

Lacustrine ostracods can be used as palaeoclimatic tracer (mainly for Quaternary). Isotopic analyses $\left({ }^{18} \mathrm{O}\right.$ and $\left.{ }^{13} \mathrm{C}\right)$ of ostracod carapaces can help to the understanding of regional events (Bahr et al. 2006; Mischke 2010) or possible exchanges between lakes and seas (Roy et al. 2011). These studies can be used in combination with protein dating by amino-acid racemization to provide valuable information on palaeotemperatures.

Environmental archaeology

These previous applications are very useful in archaeology, with a usual collection of ostracods together with plant remains, fragments of molluscs, foraminifera, bones, pollen and/or spores (Centre for Archaeology Guidelines 2002; Bates et al. 2008). Griffiths et al. (1993) provide a useful summary of sampling, preparation and identification techniques.

The shell chemistry and isotopic composition can be used even to reconstruct the climatic variations related to different periods of old cultures (e.g. Maya; Escobar et al. 2010). Changes from marine to freshwater ostracod assemblages permit to infer the end of activity in old harbour channels (Mazzini et al. 2011), whereas some ratios $(\mathrm{Mg} / \mathrm{Ca}, \mathrm{Sr} / \mathrm{Ca})$ have been utilised for understanding the evolution of prehistoric civilizations (Fig. 7: Hohokam culture, Arizona; Palacios Fest, 1997).

\section{Laboratory studies: an additional promising approach}

In numerous laboratory studies, freshwater ostracods present hopeful perspectives as biomonitors of stress conditions, giving information about the environmental state by means of the correlation between the presence/disappearance of some species, the total abundance or the population dynamics and the pollutant levels.

Herbicides and pesticides

Several experiments have analyzed the effects of variable doses of either herbicides or pesticides on different ostracod species (Fig. 8). These short studies (24-96 h of exposure time to toxins, in most cases) indicate that these microcrustaceans are excellent bioindicators, with a sensibility higher or similar to copepods, amphipods, cladocerans, crayfishes or prawns (Australian and New Zealand

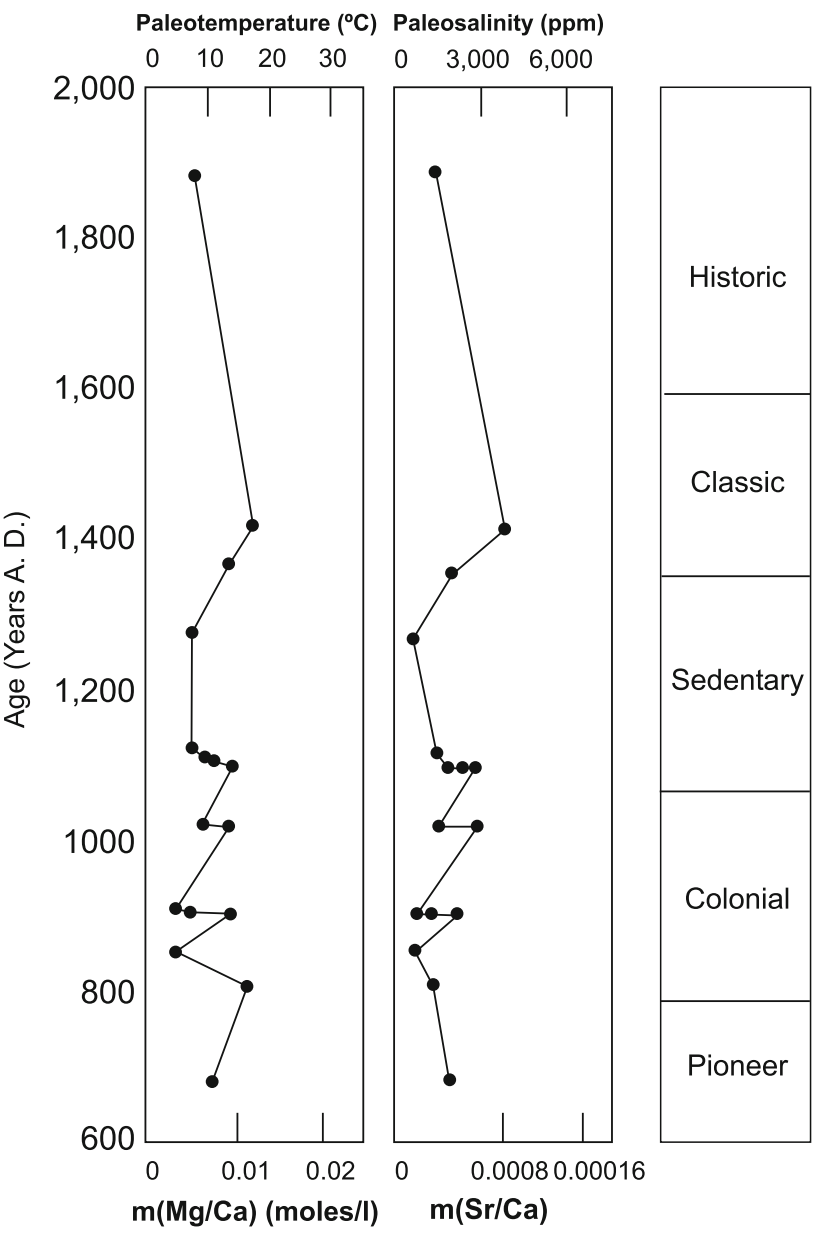

Fig. 7 Trace element palaeoenvironmental reconstruction of Hohokam canals history (Phoenix Basin Hohokam Canals, Arizona) based on ostracod shell chemistry of Limnocythere staplini (modified from Palacios-Fest 1997)

Environmental and Conservation Council 2000). Low doses of herbicides (e.g., dioxin) or pesticides (e.g., DDT, mexacarbate) cause an initial accumulation in the soft parts (Matsumura 1977), whereas increasing concentrations of other pesticides provoke intoxication, immobilisation or even mortality in the populations of Heterocypris incongruens, Cypretta spp., Eucypris sp. or Cypridopsis spp. (see Table 1 for a review).

\section{Heavy metals}

A "culture/maintenance-free" microbiotest (6-day Ostracodtoxkit $\mathrm{F}^{\mathrm{TM}}$; Chial and Persoone 2002a) has utilized the freshwater species Heterocypris incongruens (Table 2), indicating that the ostracod mortality in $\mathrm{Zn}$-polluted soils was a result of the (non-soluble) toxicants bound to the solid-phase particles, rather than of those that had dissolved in the water phase (Chial and Persoone 2003). More recently, this test is used as part of a battery of bioassays to 
Fig. 8 Impact of the organochlorine pesticide Endosulfan (a, b), the broadspectrum insecticide Rotenone (c) and two combined insecticides (d: Chlorphyrifos/ Lindane) on the ostracod populations. a, b Effect of endosulfan on total numbers \pm SE of ostracods in microcosms of Eucypris sp. and Cypretta sp. 10 weeks after initial application in southwestern Victoria, Australia (modified from Barry and Logan 1998). c Mean relative abundances (\%) of zooplankton collected in sweep-nets at five treatment levels in 18 orchard ponds in the Motueka region, New Zealand (modified from Blakely et al. 2005). d Changes in number of ostracod taxa expressed as the geometric means of the numbers counted by treatment level of Ostracoda (modified from Cuppen et al. 2002)
A
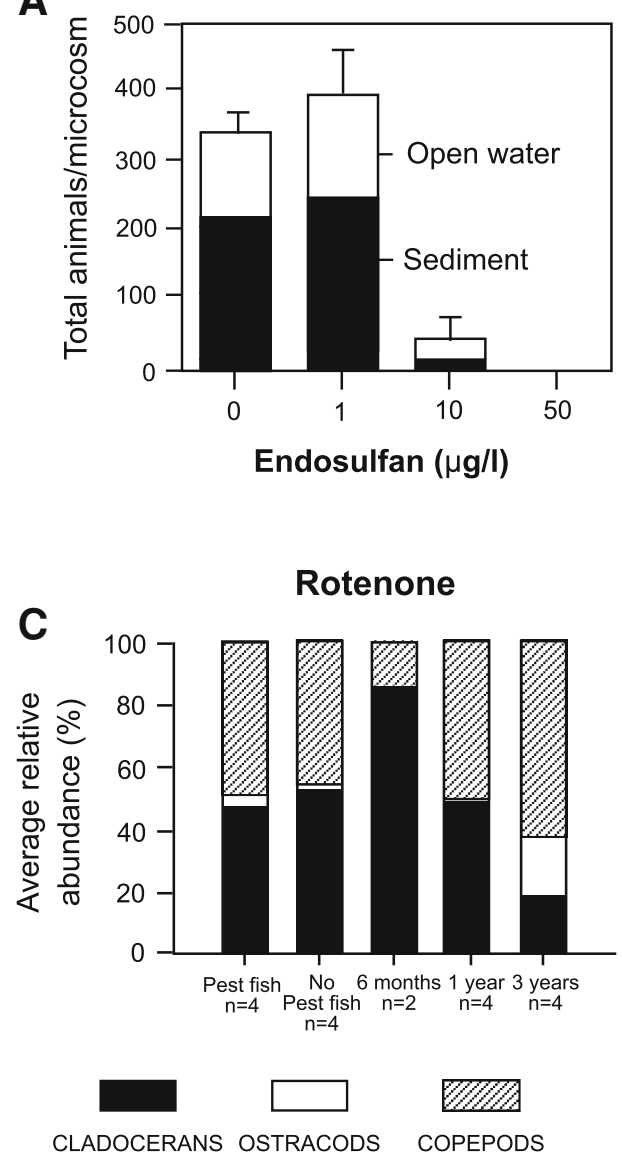

B
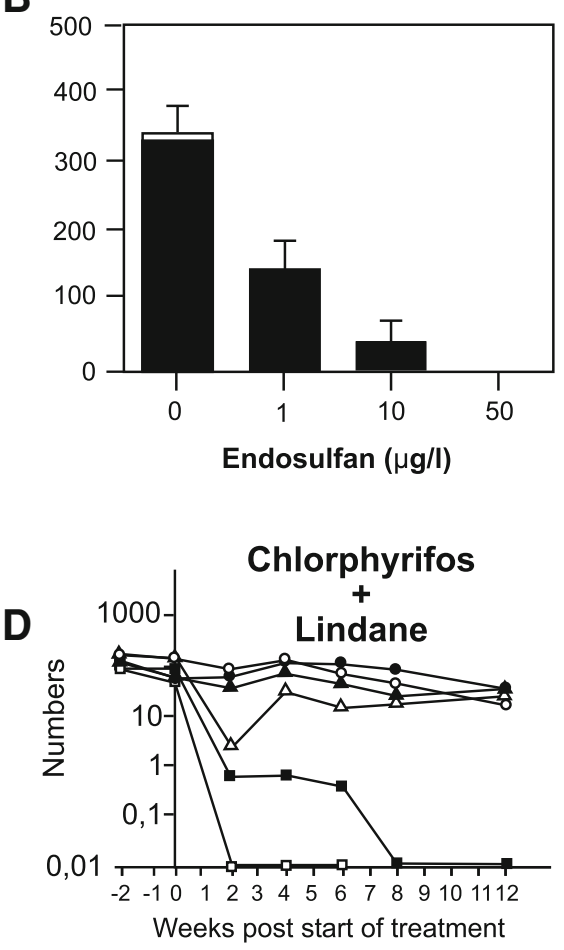

(Chlorpynfos + lindam) Concentrations $(\mathrm{mg} / \mathrm{l})$

Control A

characterize the toxicity of fluvial sediments (e.g., Wang et al. 2009).

An additional bioassay test applied to Cypris subglobosa to measure the toxicity of 36 metals and 12 reference toxicants reveals that osmium was found to be the most toxic in the test while boron, the least toxic (Khangarot and Das 2009). Increasing concentrations of $\mathrm{Cu}$ and higher acidity in waters increase the mortality on populations of this species (Khangarot and Ray 1987). This metal and Cd were included between the most toxical to Stenocypris major in other toxicological studies (Shuhaimi-Othman et al. 2011).

In these polluted waters, some freshwater species (i.e. Chrissia halyi) may survive, being the excretion a tolerance mechanisms for survival (Prasuna 1994). The efficiency of this mechanism decreases if the nominal concentration of lead in water increases (Prasuna et al. 1996). Consequently, it is necessary to analyse the relation between the metal contents of both waters and sediments and the ostracod abundance and diversity.
Oil contamination

The application of this 6-day Ostracodtoxkit ${ }^{\mathrm{TM}}$ microbiotest to oil-contaminated sediments shows that Heterocypris incongruens is more sensitive than the amphipod Hyalella azteca to contaminated sediments collected 6 and 21 weeks after oil was applied to the experimental plot. In addition, the precision of this ostracod test becomes higher or similar to that of the Hyatella test (Blaise et al. 2000; Chial et al. 2003a). In these time-related experiments, it is interesting to contrast the ostracod-amphipod results with other solidphase bioassays such a Microtox ${ }^{\circledR}$ or ASPA, which use the luminescent marine bacterium Vibrio fischeri and the unicellular freshwater chlorophyte Pseudokirchneriella subcapitata as test organisms, respectively (Blaise and Ménard 1998).

More recently, other species (e.g. Stenocypris hislopi, Cypretta seurati; Tamura et al. 2011) have been used in acute lethality tests of biodegradable lubricants. The longevity of $C$. seurati, physically more active, was strongly 
Table 1 Effects of pesticides $(\mathrm{P})$ and herbicides $(\mathrm{H})$ on the ostracod populations

\begin{tabular}{|c|c|c|c|c|c|c|c|}
\hline Name & Formula & Type & $\begin{array}{l}\text { Ostracod } \\
\text { species }\end{array}$ & $\begin{array}{l}\text { Time } \\
\text { study } \\
\text { (h) }\end{array}$ & $\begin{array}{l}\text { Toxic dose } \\
(\mu \mathrm{g} / \mathrm{l})\end{array}$ & Effect & Reference \\
\hline $\begin{array}{r}\text { Cadmium } \\
\text { chloride }\end{array}$ & $\mathrm{CdCl}_{2}$ & $\mathrm{P}$ & $\begin{array}{l}\text { Cypridopsis } \\
\text { sp. }\end{array}$ & 96 & 190 & Mortality & $\begin{array}{l}\text { Fennikoh et al. } \\
\text { (1978) }\end{array}$ \\
\hline \multirow[t]{2}{*}{ DDT } & $\mathrm{C}_{14} \mathrm{H}_{9} \mathrm{Cl}_{5}$ & $\mathrm{P}$ & $\begin{array}{l}\text { Heterocypris } \\
\text { incongruens }\end{array}$ & 24 & $0.04-1.74$ & Accumulation & Matsumura (1977) \\
\hline & & & $\begin{array}{l}\text { Heterocypris } \\
\text { incongruens }\end{array}$ & $24-48$ & $100-5,000$ & Mortality & $\begin{array}{l}\text { Khudairi and Ruber } \\
\text { (1974) }\end{array}$ \\
\hline $\begin{array}{l}\text { Dioxin }(2,3,7,8- \\
\text { TCDD })\end{array}$ & $\mathrm{C}_{12} \mathrm{H}_{4} \mathrm{Cl}_{4} \mathrm{O}_{2}$ & $\mathrm{P}$ & $\begin{array}{l}\text { Heterocypris } \\
\text { incongruens }\end{array}$ & 24 & $0.002-0.2$ & Accumulation & Matsumura (1977) \\
\hline Diquat & $\mathrm{C}_{12} \mathrm{H}_{12} \mathrm{~N}_{2}$ & $\mathrm{H}$ & N.d. & 48 & $19-46,600$ & $\begin{array}{l}\text { Two copepods were the } \\
\text { most sensitive and an } \\
\text { ostracod and a } \\
\text { cyclopoid copepod the } \\
\text { least }\end{array}$ & $\begin{array}{l}\text { Australian and New } \\
\text { Zealand } \\
\text { Environmental and } \\
\text { Conservation } \\
\text { Council (2000) }\end{array}$ \\
\hline \multirow[t]{2}{*}{ Endosulfan } & $\mathrm{C}_{12} \mathrm{H}_{4} \mathrm{Cl}_{4} \mathrm{O}_{2}$ & $\mathrm{P}$ & N.d. & $48-96$ & 0.9 & $\begin{array}{l}\text { Most sensitive were } \\
\text { copepods and ostracods }\end{array}$ & $\begin{array}{l}\text { Australian and New } \\
\text { Zealand } \\
\text { Environmental and } \\
\text { Conservation } \\
\text { Council (2000) }\end{array}$ \\
\hline & & & $\begin{array}{l}\text { Cypretta sp.; } \\
\text { Eucypris sp. }\end{array}$ & 1680 & $0-50$ & $\begin{array}{l}\text { Elimination of the total } \\
\text { population at high } \\
\text { concentrations } \\
(10-50 \mu \mathrm{g} / \mathrm{l})\end{array}$ & $\begin{array}{l}\text { Barry and Logan } \\
\text { (1998) }\end{array}$ \\
\hline Endrin & $\mathrm{C}_{12} \mathrm{H}_{8} \mathrm{Cl}_{6} \mathrm{O}$ & $\mathrm{P}$ & N.d. & $48-96$ & $0.5-74$ & $\begin{array}{l}\text { Ostracods and prawns as } \\
\text { the most sensitive } \\
\text { groups }\end{array}$ & $\begin{array}{l}\text { Australian and New } \\
\text { Zealand } \\
\text { Environmental and } \\
\text { Conservation } \\
\text { Council (2000) }\end{array}$ \\
\hline Formaldehyde & $\mathrm{CH}_{2} \mathrm{O}$ & $\mathrm{P}$ & $\begin{array}{l}\text { Cypridopsis } \\
\text { sp. }\end{array}$ & $1-96$ & $236-4,760$ & Intoxication & Bills et al. (1977a) \\
\hline \multirow[t]{2}{*}{ Lindane } & $\mathrm{C}_{6} \mathrm{H}_{6} \mathrm{Cl}_{6}$ & $\mathrm{P}$ & $\begin{array}{l}\text { Heterocypris } \\
\text { incongruens }\end{array}$ & 24 & $2.07-6.9$ & Accumulation & Matsumura (1977) \\
\hline & & & N.d. & $48-96$ & $3.2-1,100$ & $\begin{array}{l}\text { High to moderate } \\
\text { toxicity. Ostracods } \\
\text { were the most sensitive } \\
\text { group. }\end{array}$ & $\begin{array}{l}\text { Australian and New } \\
\text { Zealand } \\
\text { Environmental and } \\
\text { Conservation } \\
\text { Council (2000) }\end{array}$ \\
\hline Malachite green & $\mathrm{C}_{23} \mathrm{H}_{5} \mathrm{~N}_{2}$ & $\mathrm{P}$ & $\begin{array}{l}\text { Cypridopsis } \\
\text { sp. }\end{array}$ & $6-96$ & $2,490-8,570$ & Mortality & Bills et al. (1977b) \\
\hline Malathion & $\mathrm{C}_{10} \mathrm{H}_{19} \mathrm{O}_{6} \mathrm{PS}_{2}$ & $\mathrm{P}$ & N.d. & $48-96$ & $1.4-6.2$ & $\begin{array}{l}\text { Inmobilisation. The most } \\
\text { sensitive groups were } \\
\text { cladocerans, ostracods } \\
\text { and copepods }\end{array}$ & $\begin{array}{l}\text { Mayer and Ellersieck } \\
\text { (1986) }\end{array}$ \\
\hline Mexacarbate & $\mathrm{C}_{12} \mathrm{H}_{18} \mathrm{~N}_{2} \mathrm{O}_{2}$ & $\mathrm{P}$ & $\begin{array}{l}\text { Heterocypris } \\
\text { incongruens }\end{array}$ & 24 & $3.71-5.4$ & Accumulation & Matsumura (1977) \\
\hline Molinate & $\mathrm{C}_{9} \mathrm{H}_{17} \mathrm{NOS}$ & $\mathrm{H}$ & N.d. & $48-96$ & $180-33,200$ & $\begin{array}{l}\text { Ostracods and } \\
\text { cladocerans were more } \\
\text { sensitive than } \\
\text { crayfishes and praws }\end{array}$ & $\begin{array}{l}\text { Australian and New } \\
\text { Zealand } \\
\text { Environmental and } \\
\text { Conservation } \\
\text { Council (2000) }\end{array}$ \\
\hline Trifluralin & $\mathrm{C}_{13} \mathrm{H}_{16} \mathrm{~F}_{3} \mathrm{~N}_{3} \mathrm{O}_{4}$ & $\mathrm{H}$ & N.d. & $48-96$ & $37-2,200$ & Inmobilisation & $\begin{array}{l}\text { Australian and New } \\
\text { Zealand } \\
\text { Environmental and } \\
\text { Conservation } \\
\text { Council (2000) }\end{array}$ \\
\hline
\end{tabular}


Table 1 continued

\begin{tabular}{llllllll}
\hline Name & Formula & Type $\begin{array}{l}\text { Ostracod } \\
\text { species }\end{array}$ & $\begin{array}{l}\text { Time } \\
\text { study } \\
(\mathrm{h})\end{array}$ & $\begin{array}{l}\text { Toxic dose } \\
(\mu \mathrm{g} / \mathrm{l})\end{array}$ & Effect & Reference \\
\hline $\begin{array}{l}\text { 3- } \\
\begin{array}{l}\text { Trifluoromethyl- } \\
\text { 4-nitrophenol } \\
\text { Triflumuron }\end{array}\end{array}$ & $\mathrm{C}_{7} \mathrm{H}_{4} \mathrm{~F}_{3} \mathrm{NO}_{3}$ & $\mathrm{P}$ & $\begin{array}{c}\text { Cypridopsis } \\
\text { sp. }\end{array}$ & $1-96$ & $19,000-117,000$ & Inmobilisation & Hansen and Kawatski \\
$(1976)$
\end{tabular}

Table 2 Contrasts of the Ostracodtox kit $^{\mathrm{TM}}$ miocrobiotest with other well-known microbiotests under different experimentally induced pollution

\begin{tabular}{|c|c|c|c|}
\hline Test & Contrast & Effects & Reference \\
\hline $\begin{array}{l}\text { Hatching time, size of the cups of the } \\
\text { multiwell test plates, feeding of the rest } \\
\text { organisms prior to the test, amount of } \\
\text { supplemental algal food, volume of } \\
\text { sediment and duration of the test }\end{array}$ & $\begin{array}{l}\text { Hyalella azteca (amphipod) solid- } \\
\text { phase test }\end{array}$ & $\begin{array}{l}\text { Test protocol for a 6-day assay in 12-cup } \\
\text { multiwell plates with ten organisms per cup } \\
\text { and three replicates. Calibrated sand as } \\
\text { reference sediment. Mortality and growth } \\
\text { of the ostracods determined after } 6 \text { days } \\
\text { incubation at } 25^{\circ} \mathrm{C} \text { in darkness }\end{array}$ & $\begin{array}{l}\text { Chial and } \\
\text { Persoone } \\
\text { (2002a) }\end{array}$ \\
\hline Oil pollution & $\begin{array}{l}\text { Statistical confidence intervals } \\
\quad(95 \%)\end{array}$ & $\begin{array}{l}\text { Development of new procedures: selection of } \\
\text { a validity threshold for amount of substrate } \\
(300 \mu \mathrm{L}) \text {, number of replicates }(6) \text {, } \\
\text { mortality }(20 \%) \text { and good health of the test } \\
\text { organisms }(600 \mu \mathrm{m})\end{array}$ & $\begin{array}{l}\text { Chial and } \\
\text { Persoone } \\
\text { (2002b) }\end{array}$ \\
\hline "Culture/maintenance-free" direct contact & $\begin{array}{l}\text { Hyalella azteca (amphipod)- } \\
\text { Thamnocephalus platyurus } \\
\text { (crustacean)-Raphidocelis } \\
\text { subcapitata (microalgae) }\end{array}$ & $\begin{array}{l}\text { Complementary (nonredundant) information } \\
\text { provided by the four tests }\end{array}$ & $\begin{array}{l}\text { Chial and } \\
\text { Persoone } \\
(2002 c)\end{array}$ \\
\hline "Direct contact" toxicity determination & Springtail Folsomia candida & $\begin{array}{l}\text { Ostracod test species sensitive as or, in } \\
\text { several samples, even more sensitive than } \\
\text { the springtails. Ostracod mortality as result } \\
\text { of the (non-soluble) toxicants bound to the } \\
\text { solid-phase particles }\end{array}$ & $\begin{array}{l}\text { Chial and } \\
\text { Persoone } \\
(2003)\end{array}$ \\
\hline "Culture/maintenance-free" direct contact & $\begin{array}{l}\text { Hyalella azteca (amphipod)- } \\
\text { Midge larva Chrironomus } \\
\text { riparius }\end{array}$ & $\begin{array}{l}\text { Sensitivity quite similar between the three } \\
\text { organisms }\end{array}$ & $\begin{array}{l}\text { Chial et al. } \\
\text { (2003a) }\end{array}$ \\
\hline Oil pollution & $\begin{array}{l}\text { Hyalella azteca (amphipod) solid- } \\
\text { phase test }\end{array}$ & $\begin{array}{l}\text { Six weeks: Higher mortality of Ostracods. } \\
\text { Fifteen weeks: sediments still toxic to } \\
\text { ostracods but not to Hyalella. Lower } \\
\text { variation coefficients between replicas of } \\
\text { the ostracod results }\end{array}$ & $\begin{array}{l}\text { Chial et al. } \\
\text { (2003b) }\end{array}$ \\
\hline
\end{tabular}

affected by water pollution, with increasing adverse effects if the oleic acid used contains $\mathrm{Cu}$.

\section{Conclusion}

Freshwater ostracods are excellent bioindicators of the surrounding physical-chemical conditions, with a remarkable response to variable salinities, water depth, temperature ranges, or $\mathrm{pH}$. The ostracod carapace reflects faithfully these variations, with an interesting correlation between the water properties and both the external ornamentation and geochemical composition. Moreover, oxygen depletion, high sedimentation ratios or vigorous bottom current velocities are unfavourable factors for the development of these microcrustaceans.

The application of this dataset is very useful in palaeoclimatic reconstructions and archaeology, where the ostracod contributions are used together with additional sedimentological, geochemical or dating analyses.

Finally, in recently developed microcosm experiments, these microcrustaceans showed similar or higher sensibility 
to herbicides, pesticides, oil spills or heavy metal pollution than other traditional groups (like copepods, amphipods, bacteria), which are used to test anthropogenic impacts.

Acknowledgments This work was partially funded by three Spanish DGYCIT Projects (CTM2006-06722, CGL-2006-1412 and CGL2010-15810), a Portuguese Project (PTDC/CTE-GIX/110205/2009), an Excellence Project of the Andalusia Board (SEJ-4770) and a Group (RNM-238) of the PAIDI. This paper is a contribution to the COLASU Project (ICA3-CT-2002-10012: Sustainability of Mediterranean Coastal Lagoon Ecosystems under semi-arid climate).

Open Access This article is distributed under the terms of the Creative Commons Attribution License which permits any use, distribution, and reproduction in any medium, provided the original author(s) and the source are credited.

\section{References}

Akguc N, Ozvigit II, Yasar U, Leblebici Z, Yarci C (2010) Use of Pyracantha coccinea Roem. as a possible biomonitor for the selected heavy metals. Int J Environ Sci Tech 7:427-434

Ali A, Lord J (1980) Impact of experimental insect growth regulators on some nontarget aquatic invertebrates. Mosq News 40:564-571

Alin S, Cohen AS, Bills R, Mukwaya M, Michel M, Tiercelin K, Coveliers P, Keita S, West K, Soreghan M, Kimbadi S, Ntakimazi G (1999) Effects of landscape disturbance on animal communities in Lake Tanganika, East Africa. Conserv Biol 13:1017-1033. doi:10.1046/j.1523-1739.1999.96476.x

Altinsacli S, Griffiths HI (2001) Ostracoda (Crustacea) of Lake Uluabat (Apolyont Gölü) (Bursa Province, Turkey). Limnologica 31:109-117

Anadón P, Gabàs M (2009) Paleoenvironmental evolution of the Early Pleistocene lacustrine sequence at Barranco Leo'n archeological site (Orce, Baza Basin, Southern Spain) from stable isotopes and $\mathrm{Sr}$ and $\mathrm{Mg}$ chemistry of ostracod shells. J Paleolimnol 42:261-279

Angelo RT, Cringan MS, Chamberlain DL, Stahl AJ, Haslouer SG, Goorich CA (2007) Residual effects of lead and zinc mining on freshwater mussels in the Spring River Basin (Kansas, Missouri, and Oklahoma, USA). Sci Tot Environ 384:467-496

Australian and New Zealand guidelines for fres and marine water quality (2000) Aquatic ecosystems-rationale and background information. National Water quality management strategy. Australian Government, Australia

Bahr A, Arz HW, Lamy F, Wefer G (2006) Late glacial to Holocene paleoenvironmental evolution of the Black Sea, reconstructed with stable oxygen isotope records obtained on ostracod shells. Earth Planet Sci Lett 241:863-875

Barry MJ, Logan DC (1998) The use of temporary pond microcosms for aquatic toxicity testing: direct and indirect effects of endosulfan on community structure. Aquat Toxicol 41:101-124

Bates MR, Barham AJ, Jones S, Parfitt K, Pedley M, Preece RC, Walker MJC, Whittaker JE (2008) Holocene sequences and archaeology from the Crabble Paper Mill site, Dover, UK and their regional significance. Proc Geol Assoc 119:299-327

Bills TD, Marking LL, Chandler JH Jr (1977a) Formalin: its toxicity to nontarget aquatic organisms, persistence and counteraction. U. S. D. I., Washington, DC

Bills TD, Marking LL, Chandler JH Jr (1977b) Malachite green: its toxicity to aquatic organisms, persistence, and removal with activate coal. U. S. D. I., Washington DC
Blaise C, Ménard L (1998) A micro-algal solid phase test to assess the toxic potential of freshwater sediments. Water Qual Res J Can 33:133-151

Blaise C, Gagné F, Chèvre N, Harwood M, Lee J, Lappalainen J, Chial B, Persoone G, Doe K (2000) Toxicity assessment of oil-contaminated freshwater sediments. Environ Toxicol 19:267273

Blakely TJ, Chadderton L, Hardinng JS (2005) The effect of rotenone on orchard-pond invertebrate communities in the Motueka area, South Island, New Zealand. New Zealand Department of Conservation, Wellington

Bodergat AM (1979) Teneurs relative en phosphore, potassium et aluminium dans des carapaces d'ostracodes actuels. Interêt écologique. (Analyse à la microsonde électronique). In: Proceedings of the VII international symposium on ostracodes. Taxonomy, biostratigraphy and distribution of ostracodes, Beograd, Yugoslavia, pp 261-264

Bodergat AM (1983) Les ostracodes, témoins of leur environment: approache chimique et écologie en miliey lagunaire et océanique. Doc Lab Géol Lyon 88:1-246

Boomer I, Horne DJ, Smith RJ (2006) Freshwater Ostracoda (Crustacea) from the Assynt region, NW Scotland: new Scottish records and a checklist of Scottish freshwater species. Bull Inst R Sci Belgique Biologie 76:111-123

Boulton AJ, Scarsbrook MR, Quinn JM, Burrell GP (1997) Landuse effects on the hyporheic ecology of five small streams near Hamilton, New Zealand. N Z J Mar Freshw Res 31: $609-622$

Carbonel P, Tölderer-Farmer M (1988) The ostracod carapace as a hydrochemical source of information at water/sediment interface. In: Hanai T, Ikeya N, Ishizaki K (eds) Evolutionary biology of Ostracoda. Kodansha Ltd., Tokyo

Centre for archaeology guidelines (2002) Environmental archaeology: a guide to the theory and practice of methods, for sampling and recovery to post-excavation. English Heritage, London

Chial B, Persoone G (2002a) Cyst-based toxicity test XII-development of a short chronic sediment toxicity test with the ostracod crustacean Heterocypris incongruens: selection of test parameters. Environ Toxicol 17:520-527

Chial B, Persoone G (2002b) Cyst-based toxicity test XIII-development of a short chronic sediment toxicity with the ostracod crustacean Heterocypris incongruens: methodology and precision. Environ Toxicol 17:528-532

Chial B, Persoone G (2002c) Cyst-based toxicity test XIVapplication of the ostracod solid-phase microbiotest for toxicity monitoring of river sediments in Flanders (Belgium). Environ Toxicol 17:533-537

Chial B, Persoone G (2003) Cyst-based toxicity test XV—application of ostracod solid-phase microbiotest for toxicity monitoring of contaminated soils. Environ Toxicol 18:347-352

Chial B, Persoone G, Blaise C (2003a) Cyst-based toxicity tests XVIsensitivity comparison of the solid phase Heterocypris incongruens microbiotest with the Hyalella azteca and Chironomus riparius contact assays on freshwater sediments from Peninsula Harbour (Ontario, Canada). Chemosphere 52:95-101

Chial BZ, Persoone G, Blaise C (2003b) Cyst-based toxicity tests. XVIII. Application of ostracodtoxkit microbiotest in a bioremediation project of oil-contaminated sediments: sensitivity comparison with Hyalella azteca solid-phase assay. Environ Toxicol 18:279-283

Cohen AS, Bills R, Cocquyt CZ, Calion AG (1993) The impact of sediment pollution on biodiversity in Lake Tanganyka. Conserv Biol 7:667-677

Creuzé des Chatelliers M, Marmonier P (1993) Ecology of benthic and intersticial ostracods of the Rhone River, France. J Crustacean Biol 13:269-279 
Cuppen JGM, Crum SHJ, Van den Heuvel HH, Smidth RA, Van den Brink PJ (2002) Effects of a mixture of two insecticides in freshwater microcosms: I. Fate of chlorpyrifos and lindane and responses of macroinvertebrates. Ecotoxicology 11:165-180

Curry BB (2003) Linking ostracodes to climate and landscapes. In: Park L, Smith AJ (eds) Bridging the gap: trends in the ostracode biological and geological sciences. The Paleontological Society, Washington

Danielopol DL, Casale L, Rogulj B, Strobl J, Maier K (1990) Spatial distribution of Cytherissa lacustris in Mondsee. Bull Inst Géol Bassin d'Aquitaine 47:139-165

De Deccker P, Forester RM (1988) The use of ostracod to reconstruct continental palaeoenvironmental records. In: De Deccker P, Colin JP, Peypouquet JP (eds) Ostracoda in the earth sciences. Elsevier, Amsterdam

Dole-Olivier MJ, Galassi DMP, Marmonier P, Creuzé des Chatelliers M (2000) The biology and ecology of lotic microcrustaceans. Freshw Biol 44:63-91

Donahue I, Irvine K (2003) Effects of sediment particle size composition on survivorship of benthic invertebrates from Lake Tanganika, Africa. Arch Hydrobiol 157:131-144

Escobar J, Curtis JH, Brenner M, Hodell DA, Holmes JA (2010) Isotope measurements of single ostracod valves and gastropod shells for climate reconstruction: evaluation of within-sample variability and determination of optimum sample size. J Paleolimnol 43:921-938

Fennikoh KB, Hirshfield HI, Kueip TJ (1978) Cadmium toxicity in planktonic organisms of a freshwater food web. Environ Res 15:357-367

Fryer G (1993) Variation in acid tolerance of certain freshwater crustaceans in different natural waters. Hydrobiologia 250: $119-125$

Gliozzi E, Mazzini I (1998) Palaeoenvironmental analysis of Early Pleistocene brackish marshes in the Rieti and Tiberino intrapenninic basins (Latium and Umbria, Italy) using ostracods (Crustacea). Palaeogeogr Palaeoclimatol Palaeoecol 140:325-333

Griffiths HI, Holmes JA (2000) Non-marine ostracods and quaternary palaeoenvironments. Quaternary Research Association, technical guide 8 , London

Griffiths HI, Rouse A, Evans JG (1993) Processing freshwater ostracods from archaeological deposits, with a key to the valves of the major British genera. Circaea 10:53-62

Griffiths HI, Griffiths HI, Altinsacli S, Tzedakis C (2002) Interpreting the Tyrrhenocythere (Ostracoda) signal from Palaeolake Kopais, Central Greece. Boreas 31:250-259

Hansen CR, Kawatski JA (1976) Application of 24-hour postexposure observation to acute toxicity studies with invertebrates. J Fisher Res Boar 33:1198-1201

Hayward BW, Grenfell HR, Nicholson K, Parker R, Willmhurst J, Horrocks M, Swales A, Sabaa AT (2004) Foraminiferal record of human impact on intertidal estuarine environments in New Zealand's largest city. Mar Micropal 53:37-66

Holmes JA (1996) Trace-element and stable-isotope geochemistry of non-marine ostracod shells in Quaternary palaeoenvironmental reconstruction. J Paleolimnol 15:223-235

Holmes J, Jones R, Nicolas Haas J, McDermott F, Mohillo J, O'Connell M (2007) Multi-proxy evidence for Holocene lakelevel and salinity changes at An Loch Mór, a coastal lagoon on the Aran Islands, Western Ireland. Quat Sci Rev 26:24382462

Hugueney M, Poidevin JL, Bodergat AM, Caron JB, Guérin C (1999) Des mammifères de l'Aqutanien inférieur à La Roche-BlancheGergovie (Puy-de-Dôme, France), révélateurs de l'activité postoligocène du rift en Limagne de Clermont. Comptes Rend Acad Sci 328:847-852
Ikeya N, Hanai T (1982) Ecology of recent ostracods in the HamanaKo region, the Pacific Coast of Japan. In: Hanai T (ed) Studies on Japanese Ostracoda. University of Tokyo, Tokyo

Jin Z, Bickle MJ, Chapman HJ, Yu J, An Z, Wang S, Greaves MJ (2011) Ostracod $\mathrm{Mg} / \mathrm{Sr} / \mathrm{Ca}$ and ${ }^{87} \mathrm{Sr} /{ }^{86} \mathrm{Sr}$ geochemistry from Tibetan lake sediments: implications for early to mid-Pleistocene Indian monsoon and catchment weathering. Boreas 40:320-331

Keyser D (2005) Histological peculiarities of the noding process in Cyprideis torosa (Jones) (Crustacea, Ostracoda). Hydrobiologia 538:95-106

Khangarot BS, Das S (2009) Acute toxicity of metals and reference toxicants to a freshwater ostracod, Cypris subglobosa, and correlation to $\mathrm{EC}_{50}$ values of other test models. J Hazard Mat 172:641-649

Khangarot BS, Ray PK (1987) The response to a fresh-water ostracod (Cypris subglobosa Sowerby) exposed to copper at different $\mathrm{pH}$ levels. Acta Hydrochim Hydrobiol 15:553-558

Külköylüoglu O (2004) On the usage of ostracods (Crustacea) as bioindicator species in different aquatic habitats in the Bolu region, Turkey. Ecol Indic 4:139-147

Külköylüoglu O, Yilmaz F (2006) Ecological requirements of Ostracoda (Crustacea) in three types of spring in Turkey. Limnologica 36:172-180

Lambert P (1997) La sedimentation dans le Lac de Neuchâtel (Suisse): processus actuels et reconstitution paléoenvironmentale de 1500 BP à nos jours. Ph.D. thesis, Neuchâtel University, Switzerland

Lawrence JR, Packroff G, Neu TR (2002) Microscale evaluation of the effects of grazing by invertebrates with contrasting feeding modes on river biofilm architecture and composition. Microb Ecol 44:199-207

Li X, Liu W, Zhang L, Sun Z (2010) Distribution of recent ostracod species in the Lake Qinghai are in northwestern China and its ecological significance. Ecol Indic 10:880-890

Lim RP, Wong MC (1986) The effects of pesticides on the population dynamics and production of Stenocypris major Baird (Ostracoda) in ricefields. Archiv Hydrobiol 106:421-427

Lord A, Cabral MC, Dambeck R, Kunst M (2011) Ostracod evidence for the neolithic environment of Rioz Sizandro, Portugal. Palaeobiodiv Palaeoenviron 91:215-228

Lu XW, Yang C, Dang Z (2009) Preliminary investigation of chloramphenicol in fish, water and sediment from freshwater aquaculture pond. Int J Environ Sci Tech 6:597-604

Marmonier P, Bodergat AM, Doledec S (1994) Theoretical habitat templets, species traits, and species richness: ostracods (crustacea) in the Upper Rhône River and its floodplain. Freshw Biol 31:341-355

Martens K, Tudorancea C (1991) Seasonally and spatial distribution of the ostracods of Lake Zwai, Ethiopia (Crustacea: Ostracoda). Freshw Biol 25:233-241

Martin-Rubio M, Rodríguez-Lázaro J, Anadón P, Robles F, Utrilla R, Vázquez A (2005) Factors affecting the distribution of recent lacustrine ostracoda from the Caicedo de Yuso-Arreo Lake (Western Ebro Basin, Spain). Palaeogeog Palaeoclimatol Palaeoecol 225:118-133

Matsumura F (1977) Adsorption, accumulation, and elimination of pesticides by aquatic organisms. In: Khan MAA (ed) Pesticides in aquatic environments. Plenum Press, New York

Mayer FLJ, Ellersieck MR (1986) Manual of Acute toxicity: interpretation and data base for 410 chemicals and 66 species of freshwater animals. Department of Interior, US Fish and Wildlife, Washington DC

Mazzini I, Faranda C, Giardini M, Giraudi C, Sadori L (2011) Late Holocene palaeoenvironmental evolution of the Roman harbour of Portus, Italy. J Paleolimnol 46:243-256 
Meisch CK (2000) Freshwater Ostracoda of Western and Central Europe. Spektrum Akademischer Verlag, Heidelberg

Mezquita F, Hernández R, Rueda J (1999a) Ecology and distribution of ostracods in a polluted Mediterranean river. Palaeogeog Palaeoclimat Palaeoecol 148:87-103

Mezquita F, Griffiths HI, Sanza S, Soria JM, Pinon A (1999b) Ecology and distribution of ostracods associated with flowing waters in the Eastern Iberian. J Crustacean Biol 19:344-354

Milhau B, Dekens N, Wouters K (1997) Evaluation de l'utilisation des ostracodes comme bio-indicateurs potentiels de pollution. Application aux eaux de la Slack (Boulonais, France). Ecologie 28:3-12

Mischke S (2010) Ostracods and stable isotopes of a late glacial and Holocene lake record from the NE Tibetan Plateau. Chem Geol 276:95-103

Modig H, Van den Bund WJ, Olafsson E (2000) Uptake of phytodetritus by three ostracod species from the Baltic Sea: effects of amphipod disturbance and ostracod density. Mar Ecol Prog Ser 202:125-134

Mourguiat P, Carbonel P, Peypouquet JP, Wirrmann D, Vargas C (1986) Late quaternary palaeohydrology of Lake Huinaymarca (Bolivia). Hydrobiologia 143:191-197

Onderikova V (1993) Herpetocypris chevreuxi G. O. Sars, 1896 (Crustacea, Ostracoda)-un éliminateur important de la pollution organique des eaux usées. Bull Soc Nat Luxembourg 94:233-240

Palacios-Fest MR (1997) Paleoenvironmental reconstruction of human activity in Central Arizona using shell chemistry of Hohokam Canal Ostracodes. Geoarchaeology 12:211-226

Pieri V, Vandekerkhove J, Goi D (2012) Ostracoda (Crustacea) as indicators for surface water quality: a case study from the Ledra River basin (NE Italy). Hydrobiologia 688:25-35

Pipik R, Bodergat AM (2005) Espèces du groupe de Candona candida, Candona neglecta et quelques Candona à l'aspect morphologique problématique (Candonidae, ostracoda) du bassin de Turiec (Miocène supérieur, Slovaquie). Ann Paléont 91:279-309

Piyatiratitivorakul P, Boonchamoi P (2008) Comparative toxicity of mercury and cadmium to the juvenile freshwater snail, Filopaludina martensi martensi. Sci Asia 34:367-370

Poquet JM, Mezquita F, Rueda J, Miracle AR (2008) Loss of Ostracoda biodiversity in Western Mediterranean wetlands. Aquat Conserv Mar Freshw Ecosyst 18:280-296

Prasuna G (1994) Ecological adaptations of Chrissia halyi and their role in bioaccumulation and biomagnification of lead. Ph.D. Thesis, Osmania University, Hyderabad

Prasuna G, Zeba M, Khan MA (1996) Excretion of Lead as a Mechanism for Survival in Chrissia halyi (Ferguson, 1969). Bull Environm Contam Toxicol 57:849-852

Ramdani M, Flower RJ, Elkhiati N, Birks N, Kraiem MM, Fathi AA (2001) Zooplankton (Cladocera, Ostracoda), Chironomidae and other benthic faunal remains in sediment cores from nine North African wetland lakes: the CASSARINA Project. Aquat Ecol 35:389-403

Rieradevall M, Roca JR (1995) Distribution and population dynamics of ostracodes (Crustacea, Ostracoda) in a karstic lake: Lake Banyoles (Catalonia, Spain). Hydrobiologia 310:189-196

Rimet F, Bouchez A (2011) Use of diatom life-forms and ecological guilds to assess pesticide contamination in rivers: Lotic mesocosm approaches. Ecol Indic 11:489-499

Rinderhagen M, Ritterhoff J, Zauke GP (2000) Crustaceans as bioindicators. In: Gerhart A (ed) Biomonitoring of polluted water-reviews on actual topics. Trans Tech Publications-Scitech Publications, Zurich
Rio M, Bodergat AM, Carbonnel G, Keyser D (1997) Anisotropie chimique de la carapace des ostracodes. Exemple de Leptocythere psammophila. Compt Rend Académ Sci 324:827-834

Rosenfeld A, Vesper B (1977) The variability of the sieve-pores in recent and fossil species of Cyprideis torosa (Jones, 1850) as an indicator for salinity and paleosalinity. In: Löffler H Danielopol DL (eds) Aspects of ecology and zoogeography of recent and fossil Ostracoda. Dr. W. Junk publishers, The Hague

Rosetti G, Bartoli M, Martens K (2004) Limnological characteristics and recent ostracods (Crustacea, Ostracoda) of freshwater wetlands in the Parco Oglio Sud (Northern Italy). Int J Limnol 40:329-341

Rossi V, Benassi V, Veneri M, Bellavere C, Menozzi P, Moroni A, Mckenzie KG (2003) Ostracoda of the Italian ricefields thirty years on: new synthesis and hypothesis. J Limnol 62:1-8

Roy M, Dell'Oste F, Veillette JJ, de Vemal A, Hélie JF, Parent M (2011) Insights on the events surrounding the final drainage of Lake Ojibway based on James Bay stratigraphic sequences. Quat Sci Rev 30:682-692

Ruiz F, González-Regalado ML, Menegazzo-Vitturi L, Pistolato M (1998) Los ostrácodos de los sedimentos litorales del NE de Italia. I: El río Adige. Stvd Geol Salmanticen 34:3-13

Ruiz F, Rodríguez Ramírez A, Cáceres LM, Rodríguez Vidal J, Carretero MI, Clemente L, Muñoz JM, Yáñez C, Abad M (2004) Late Holocene evolution of the southwestern Doñana National Park (Guadalquivir Estuary, SW Spain): a multivariate approach. Palaeogeogr Palaeoclimatol Palaeoecol 204:47-64

Saunders DL, Meewig DL, Vincent CJ (2002) Freshwater protected areas: strategies for conservation. Conserv Biol 16:30-41

Shuhaimi-Othman M, Yakub N, Ramle N, Abad A (2011) Toxicity of metal to a freshwater ostracod: stenocypris major. J Toxicol 2011:136104

Suren AM (1992) Meiofaunal communities associated with bryophytes and gravels in shaded and unshaded alpine streams in New Zealand. N Z J Mar Freshw Res 26:115-125

Tamura S, Ezoe S, Sasaki C (2011) Bioassay technique using seed shrimps for comparative studies regarding the aquatic acute lethality of biodegradable lubricants. Ecotoxicol Environ Safety $74: 1578-1585$

Van der Merwe C (2003) The assessment of the influence of treated underground mine water on the benthic fauna in a portion of the Blesbokspruit Ramsar Site. Mini-thesis for Magister Artium in Environmental Management. Rand Afrikaans University, South Africa

Vesper B (1975) To the problem of noding on Cyprideis torosa (Jones, 1850). Bull Am Paleont 65:205-215

Wang F, Leung AOW, Wu SC, Yang MS, Wong M (2009) Chemical and ecotoxicological analyses of sediments and elutriates of contaminated rivers due to e-waste recycling activities using a diverse battery of bioassays. Environ Pollut 157:2082-2090

Wünnemann B, Mischke S, Chen F (2006) A holocene sedimentary record from Bosten Lake, China. Palaeogeogr Palaeoclimatol Palaeoecol 234:223-238

Yilmaz F, Külköylüoglu O (2006) Tolerance, optimum ranges, and ecological requirements of freshwater Ostracoda (Crustacea) in Lake Aladağ (Bolu, Turkey). Ecol Res 21:165-173

Zhai D, Xiao J, Zhou L, Wen R, Chang Z, Pang Q (2010) Similar distribution pattern of different phenotypes of Limnocythere inopinata (Baird) in a brackish-water lake in Inner Mongolia. Hydrobiologia 651:185-197

Zhu X, Venosa A, Suidan MT, Lee K (2001) Guidelines for the remediation of marine shorelines and freshwater wetlands. US Environmental Protection Agency, USA 